\title{
THE SUSTAINABILITY OF HERITAGE BUILDINGS: REVITALIZATION OF BUILDINGS IN THE BANDUNG CONSERVATION AREA, INDONESIA
}

\author{
NURTATI SOEWARNO, TAUFAN HIDJAZ \& EKA VIRDIANTI \\ Institut Teknologi Nasional Bandung, Indonesia
}

\begin{abstract}
A city is a human creation that always experiences development. As time goes by, the development of the city sometimes does not go according to the initial plan. In Indonesia, major cities were planned and built during the Dutch colonial era, based on good planning for several decades into the future. After Indonesian independence, a lot of obstacles were faced by cities, so their development shifted away from the initial plan. This paper will describe the development of an initially residential area for Dutch society within Bandung city. Today, the area is declared as one of the cultural heritage areas, because of its history and the architectural style of the buildings. Some investors have considered the environment plan, location and unique architectural style of buildings in this area as having potential that they could profit from, so one by one the residential buildings in this area transferred into commercial ones. How does transformation occur with conservation buildings as part of a cultural heritage? What kind of revitalization can be performed to adapt to their new function? It is expected that the revitalization performed will sustain cultural heritage buildings within this conservation area. Keywords: Bandung, city development, conservation area, Dutch colonial architecture, heritage buildings, Indonesia, remodeling, repurposing, revitalization.
\end{abstract}

\section{INTRODUCTION}

Even though Indonesia has now been independent for 73 years, the evidence that the Dutch colonists once settled in Indonesia can still be felt. One kind of evidence is the buildings that remain; places where the Dutch used to do their activities, such as oversee the settlement, offices, do trading and run industry. These building can easily be distinguished by the architectural building styles. The district where those buildings are located is set up as a conserved area, as are the buildings.

The rapid development and rise of the city economically has caused the buildings to be unsuitable for settlement anymore. Also, the high tax price and the high building maintenance costs have become significant factors.

Nowadays, in some previously Dutch residential areas, the buildings tend to experience a functionality shift, to become commercial buildings. Having a commercial function is considered more appropriate, to resolve the tax and maintenance problems. The buildings' functional transformation is rated appealing, because it both meets commercial needs and becomes an effort towards the preservation of heritage buildings.

The adaptive re-use method is considered the right method to apply to add building functions and shapes, according to commercial demands, yet still comply with the appointed laws for buildings and cultural heritage areas. By applying this method, it is expected that the revitalization of the conserved area could be run well and the beauty of the colonial buildings as a cultural heritage could be enjoyed by the public, not only becoming a symbol of the presence of the colonial era in Indonesia. 


\section{LITERATURE REVIEW}

\subsection{Conservation area}

Bandung has many historical buildings whose form of architecture is inseparable from heritage buildings of the colonial era. The distribution of these buildings is clustered among several city streets in Bandung. Perda Bandung (Bandung Government Regulation) No. 19, year 2009, categorizes these clusters into six conservation areas. Riau Street is one of the corridors that belong to the category of defence and security areas, where heritage buildings stand but formerly functioned as military buildings. Over time, the building sustainability in this area has been threatened by modernization. Therefore, it is considered important to preserve the historical value of these colonial buildings, through conservation. Conservation may include all maintenance activities and also to get adapted to local circumstances comprising preservation, reconstruction and adaptation; so that all provide new life for the development of the area, as well as improvements in the quality of life of the community (including users, visitors) and the quality of the environment [1].

\subsection{Revitalization}

Challenges between the theory and practice of conservation comes, in the future, from not only the object or historic areas, but also from the context associated with the surrounding community. One way to organize a conservation area or a building is to revitalize it. Revitalization is an effort to empower the situation and condition of an area and/or a heritage building for various functions that will support its preservation [2]. Providing a variety of new functions is a sustainable design approach for consideration of adaptive habits, needs and patterns formed on the environment and surrounding communities [3].

\subsection{Building transformation}

Building transformation is an adaptation process aiming to revive the functionality of a building and to sustain it. The transformation process is divided into three categories by Amos Rapoport, namely [4]:

1. Core element: the transformation of the element of a building that is slowly changed and becomes the identity of the owner of the architecture;

2. Peripheral element: the transformation of unimportant elements, and how it is easily changed or replaced;

3. New element: the transformation as an adaptation of the owner of a new culture. It becomes a part of the architecture. Because the transformation occurs to conserved buildings, a certain strategy is needed. According to Plevoets and Cleempoel [5] the strategic approaches in heritage buildings include: Building within; building over; building around; building alongside; recycling of materials; adapting for new functionalities; and building style.

\section{RIAU STREET AS CASE STUDY}

\subsection{Location}

Riau Street stretches $3 \mathrm{~km}$ long, from the West to the East part of Bandung. This is the primary collector street that connects some important places in Bandung. This street crosses some other streets, so it can be divided into five segments, which are: 
- Segment 1: It is only 298.4 meters long and consists of offices and hotels.

- Segment 2: The length of this segment is $236.6 \mathrm{~m}$. There is only one residential building left, which is the house of the Siliwangi commander (West Java army). The rest of the buildings are now hospitals, a mall and hotels.

- Segment 3: In this $482.6 \mathrm{~m}$ long segment, the majority of the buildings are still used as military offices and guest houses. The rest of the buildings are hospitals, colleges and factory outlets.

- $\quad$ Segment 4: This segment is the longest $(1,358.9 \mathrm{~m})$ and the most crowded one. The buildings are varied, but include residential houses, a public health laboratory, a court, offices, a bank, a church, a hotel, restaurants and fashion boutiques.

- Segment 5: The last segment is $616.2 \mathrm{~m}$ in length and only has a few residential buildings left. Some buildings have already changed into restaurants, a hotel, cake shops, banks, offices and guest houses.

\subsection{Historical background}

Bandung began as a residential area settled by the Dutch East Indies colonial government, through a decree of then Governor-General Herman Willem Daendels, dated 25 September 1810, upon the commencement of construction of facilities and infrastructure for the new urban areas. This decision became the base for the construction of a railroad connecting Bandung to Batavia, in the $1880 \mathrm{~s}$. After the project was completed, Bandung officially got the gemeente (municipality) status from then Governor General J.B. van Heutsz, on April 1, 1906. With the status of gemeente, the Dutch then began making the technical design of Bandung's new urban development project, and its physical construction started in 1918.

The new city project of Bandung was handled by a group of technicians led by Retired Colonel Zeni of Military Dutch VL Slors, serving as Director of Building Service Gemeente Bandung. One of the team's architects was Ir. J. Gerber, who planned Gedung Sate, which later became the main work of the architectural building style representing the Indo Europeeschen Architectuur Stijl or Indo-European Architecture Style.

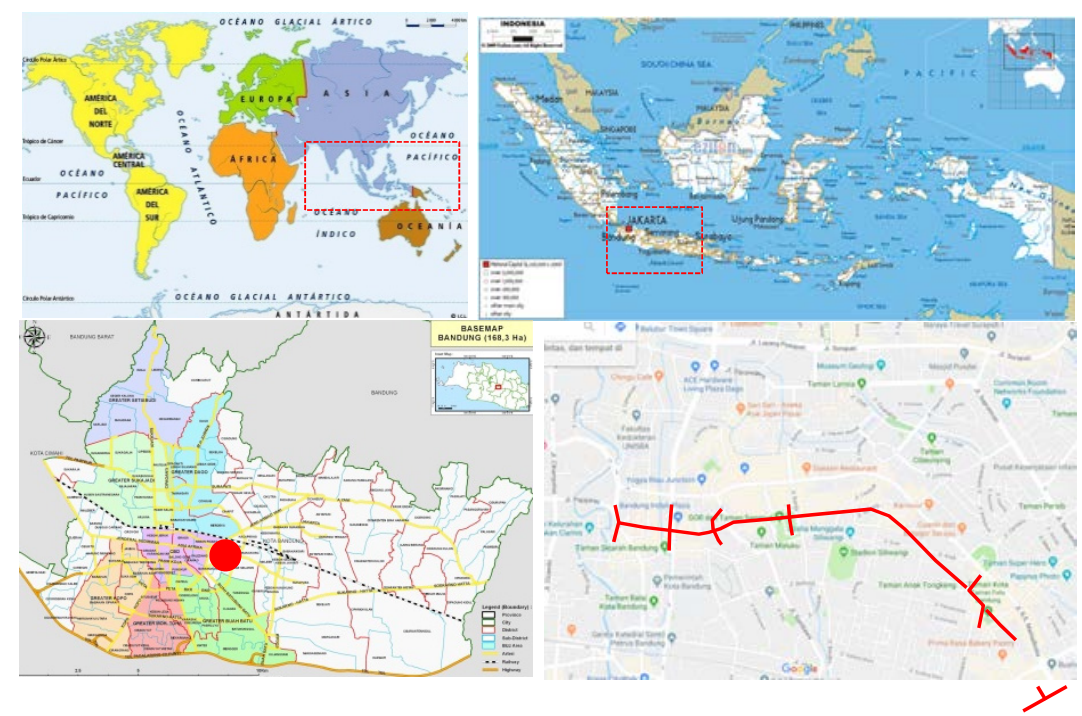

Figure 1: The location of Riau Street in Indonesia. (Source: Edited material from Google Maps, 2018.) 
The Riau Street area (Riaw stratt) was a part of the plan to develop the city of Bandung; and after the independence from Indonesia, the street changed into Jalan LLRE Martadinata. This street extends around $3 \mathrm{~km}$ long, from Jalan Ahmad Yani to Jalan Merdeka, at the junction of Jalan Ir H Juanda (Dago Street). Riau Street and the housings on it were built to support the area for the European Community Activity Centre (Europeesche Zakenwijk) in the city of Bandung, which covered the NE region around Gedung Sate and Insulindepark, currently Taman Nusantara or Traffic Garden. Some other supporting buildings were the Jaarbeurs Building (the place for the annual market) on Aceh Street and the surrounding housing complex. This fact is embodied in the explanation of the development of Bandung called Uitbreidingsplannen der Gemeente Bandung, published in 1919 by the Commission for Assessment of the Bandung Development Plan [Commissie voor de Beoordeeling van de Uitbreidingsplannen der Gemeente Bandoeng], headed by E.H. Karsten.

This central area for European society became an elite area, because it was perfectly designed by Col. Ret. V.L. Slors and comrades, so it could attract the attention of Maestro architect Hendrik Petrus Berlage from the Netherlands. Considered a good design, Berlage called this area the "Indische Koloniaal Staad" upon his arrival in Bandung in 1923. Hendrik Berlage then took it as material for a paper in the International Congresses of Modern Architecture (Congres Internationaux d'Architecture Moderne or CIAM) at the Chateau de la Sarraz, Switzerland, in June 1928 [6].

The first major building on Riau Street was the residence of Gouvernements Bedrijven (Government Company) [7]. The white building influenced by Renaissance style combined with art deco was built during 1895-1905. In 1984, it was used by The British Institute for an English course; and since the year 1999, it has been used as a Factory Outlet under the name "Heritage".

Along Riau Street were built housing for the high-ranking officials of the Dutch colonial government. The building style is called Indo Europeeschen Architectuur Stijl [8], which has a combination of European and Indonesian styles in an effort to adjust to the tropical climate. The height of the building was copied from European-style buildings; meanwhile, the roof was copied from Indonesian traditional buildings. The canopy was placed as an addition to resist sunshine and rain.

To complete the area the Dutch government also built a park, which was called Oranje Plein (the Orange Park or Taman Pramuka) at the Eastern end of Riau Street, surrounded by rental villas. In 1920 they built a building that served as a garden café, a meeting place for the Dutch people in Bandung (currently called Gedung Pramuka) inside the park. This building still exists today. In the vicinity of the Oranje Plein, there are 19 modern multi-story residential units that were built by $\mathrm{D}$. H. Ton as rental houses or motels, or pension residences for tourists. One of the buildings was known as "Lux Vincet", of which L.W. Huisman was the manager [7].
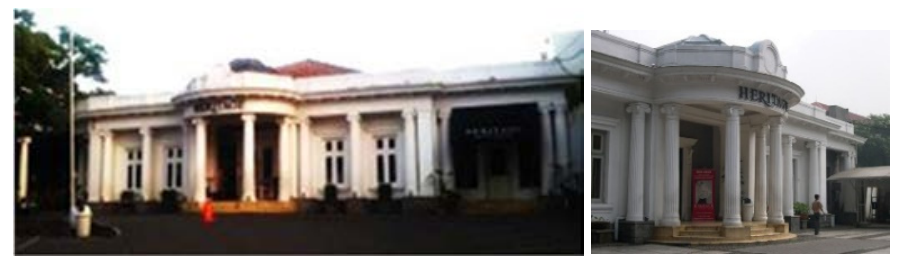

Figure 2: The first building in Riau Street 63 was an official residence of the Director of Government Companies. (Source: Katam, 2010.) 


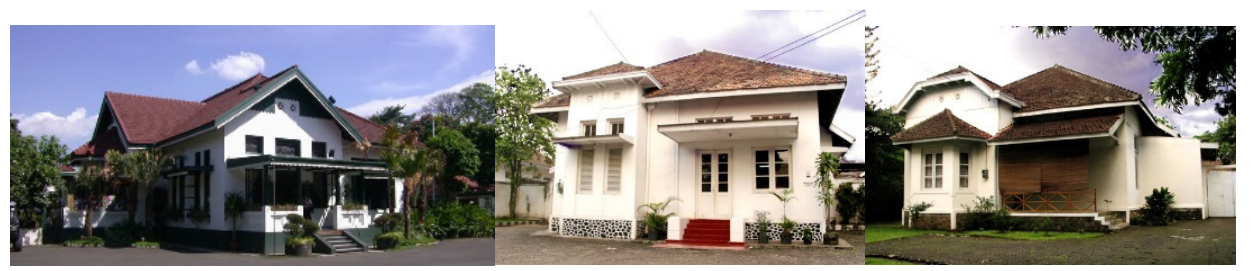

Figure 3: Some of Colonial buildings with Indo-European Style that still exist on Riau Street. (Source: Survey result, 2018.)

\subsection{Current situation}

In the era of Indonesian independence, this area was occupied by the West Java Army. Those buildings functioned as offices and residential housing for the Indonesian Army officers.

Since the year 2000 many changes have occurred, and Riau Street has become one of the most interesting streets in Bandung. By changing the function of some colonial residential houses into Factory Outlets, Cafés and Clothing Boutiques; nowadays Riau Street has become one of the tourist destinations in Bandung. Due to that fact, the government has renovated the corridor by putting some architectural elements, such as creating comfortable pedestrian sidewalks. Conveniently, this sidewalk connects the stores.

Most building transformation has eliminated the residential function; and thus, caused the area to become commercial. This paper will take some cases from segments 4 and 5, where many building transformations have occurred.

\section{THE TRANSFORMATION}

Several cases were selected to further study about the transformation that occurred on Riau Street. Three study cases were chosen from two segments (segments 3 and 5), based on the typology of transformation.

\subsection{Case 1: Heritage, the factory outlet}

This building, located in segment 3 at the corner of Riau Street and Banda Street, with the long side facing Riau Street. The architecture style was influenced by the Renaissance style, shows the skill to make a flat area more beautiful, rationally. The uniqueness of the

Table 1: Present time building function. (Source: Survey result, 2018.)

\begin{tabular}{|l|c|c|c|}
\hline \multirow{2}{*}{ Building function } & \multicolumn{3}{|c|}{ Location } \\
\cline { 2 - 4 } & Segment 3 & Segment 4 & Segment 5 \\
\hline Residential & 6 & 23 & 13 \\
\hline Office & 3 & 18 & 11 \\
\hline College/school & - & 6 & 1 \\
\hline Commercial & 23 & 31 & 17 \\
\hline Hospital & 3 & 3 & - \\
\hline Worship & - & 1 & - \\
\hline
\end{tabular}


architecture style made this building be listed as Conservation Building Type A, which means it is not permitted to be demolished or changed, as per government ruling.

Most attractive and interesting in this building is semi-circular main entrance, with a polygonal form of canopy. This shape represents the influence of the Baroque style, which at this time was very scarce and hard to find in Bandung. Other specifications which admit being defended are the pillars. These columns are in the facade and located at the right side of the building, with engravings following the Doric style. They create a sturdy and strong impression of the building. The long side of the building represents the biggest area facing Riau Street, with a harmonious regular rhythm for the window's ornamentations and shapes (Fig. 4) [9].

The transformation began since this building was occupied by the Indonesian government. In the year 1984, the building was rented by a private company for giving English courses; and then, for Private courses for Bank Managers. It was then abandoned for several years, but in the year 2000 it was rented by a businesswoman and changed into "Heritage the Factory Outlet" until the present time. The success of this factory outlet owner was followed by other investors raising similar businesses, using the ex-colonial buildings nearby along Riau Street. A factory outlet needs more space for clothing display and separate places are needed for men, ladies, and children; and there are sections for other needs. In the back yard is a two-story building that was built for the men and children's clothing sections. Beside that, a transparent non-permanent cafeteria was built to the left side, to support visitor needs.

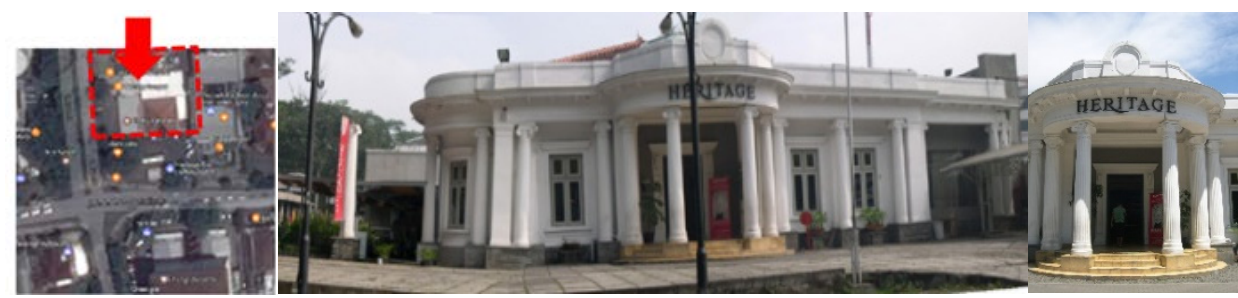

Figure 4: The location and front elevation of the "Heritage" factory outlet building. (Source: Edited from Google maps, 2018 and Nurtati Soewarno, 2005.)
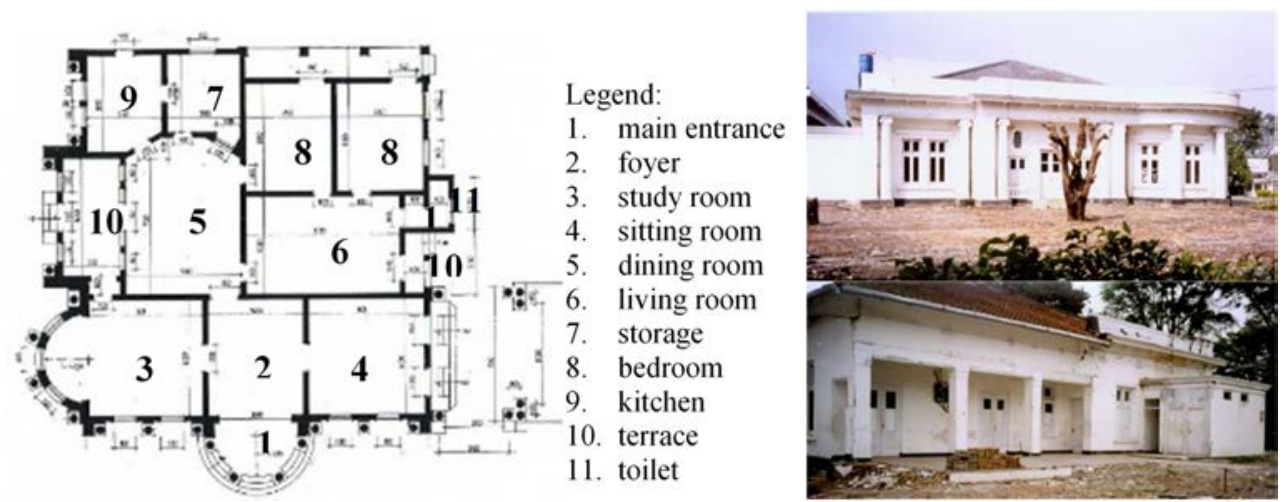

Figure 5: Building plan, left and back side elevation, before it was used as a factory outlet. (Source: Nurtati Soewarno, 2005.) 
In line with the building's fashion development, clothes production also increased, so that more new fashion displays and sales stations were needed. Therefore, a new shop was built on the right side.

In contrast with "Heritage" this new building used a modern style and to make easy access, a connecting door was created. The increase in visitors caused a lack of parking lots, so the rest of the garden is now used for parking space (Fig. 6).

\subsection{Case 2: The sleeping forest restaurant}

This building was located in segment 5 and built in the year 1920 as the residence for a government officer. The building was made applying Indo-European architecture style, which adapts to the tropical climate: a 45-degree roof slope, big windows, a high ceiling and canopy. It is listed as Conservation Building Type B, which must have its façade maintained.

Used as an Army officer's residence after independence and until the year 2017.

The transformation began since it was to be used as a Restaurant named Sleeping Forest. As a restaurant, there was a lack of space for the dining room, kitchen, service area and storage. To fulfil these requirements, a 3-story circular building was built at the back side for the dining area and this becomes the visitor's main destination.

The new building applied the contrast concept, using different materials and having a different building shape, a circle to make the old building predominate.

Additional rooms were needed for a toilet, a prayer room, and a pantry and were placed on the first floor.

There was a lack of parking space, so the front garden is used as a parking area. On the first floor, the old building is used as the lobby, cashier counter, office and kitchen. Meanwhile the additional building is used as the service area, storage, employee room, prayer room and toilet. The 3-story additional building is used as an open-space dining area.
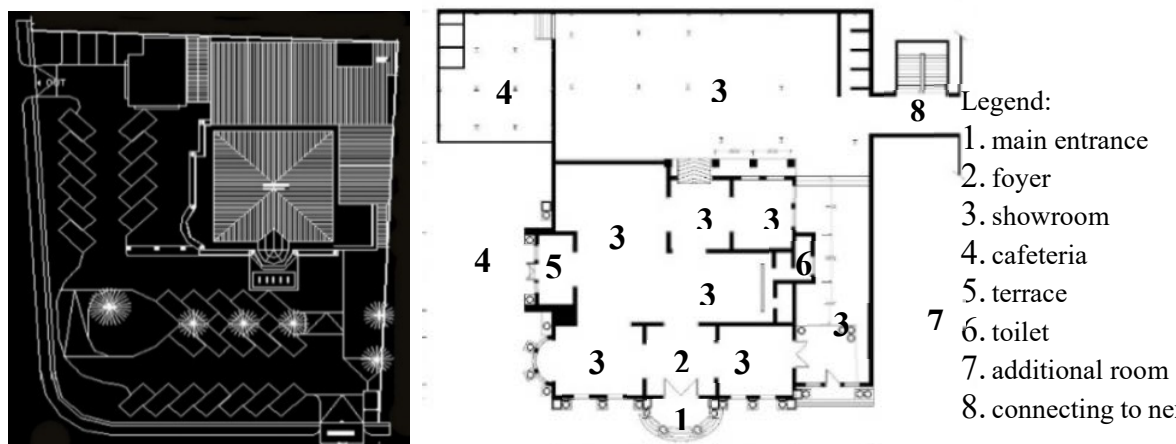

8 . connecting to next door

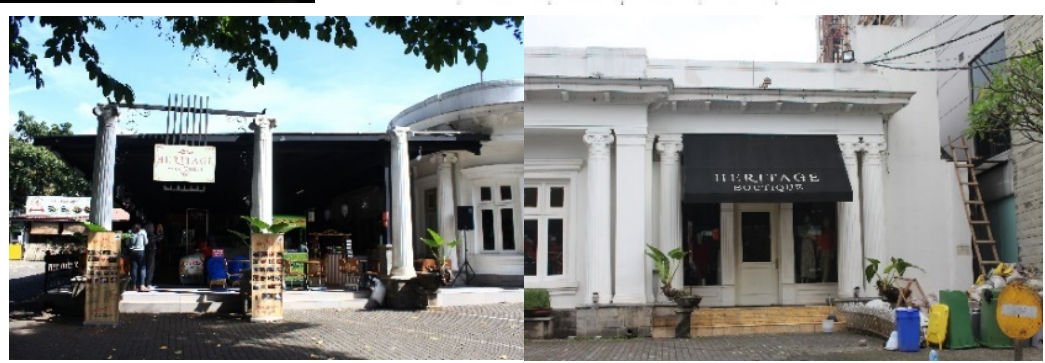

Figure 6: Current situation: site plan, building plan, transparent cafeteria and additional room. (Source: Nurtati Soewarno, 2005.) 


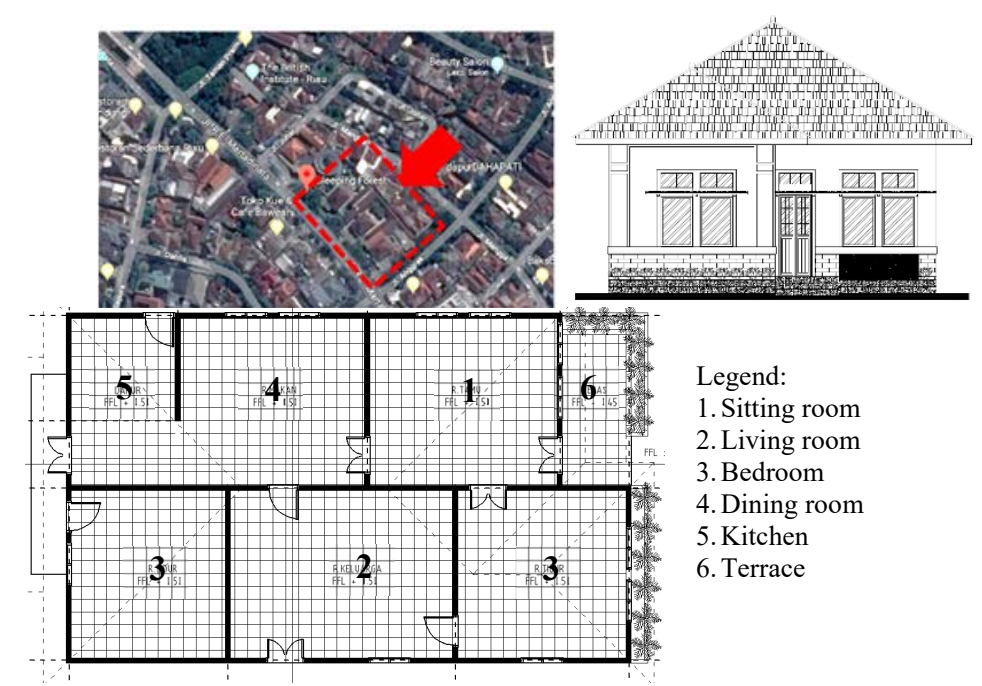

Figure 7: The location, front elevation and original building plan. (Source: Karina Khoerunnisa et al., 2005 [10].)

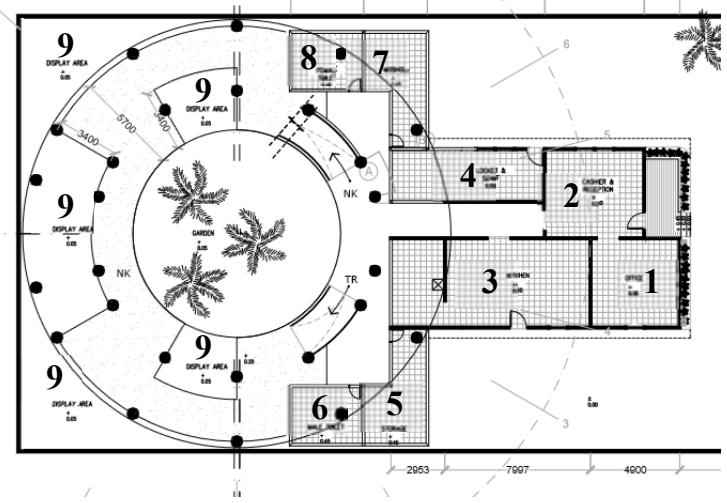

Legend:

1. Office

2. Cashier and Reception

3. Kitchen

4. Locker and staff

5. Storage

6. Male toilet

7. Musholla (prayer room)

8. Female toilet

9. Dining area

Figure 8: Current building plan, rooms 1 to 4 are from the original plan. (Source: Karina Khoerunnisa et al., 2017 [10].)
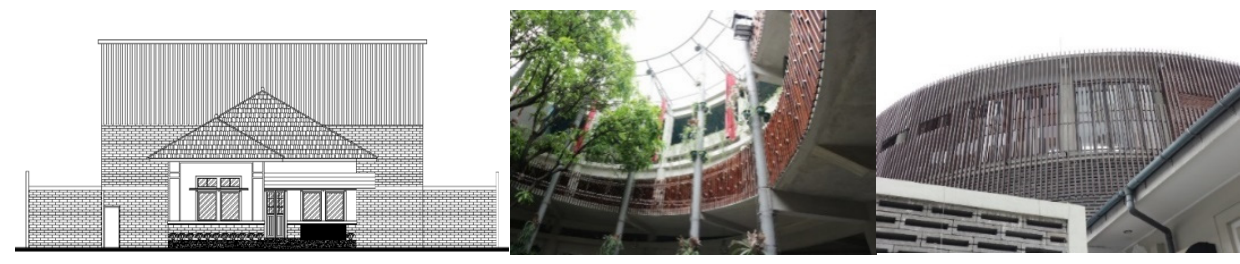

Figure 9: Front elevation and the circular building as the back grounds. (Source: Karina Khoerunnisa et al., 2017 [10].) 


\subsection{Case 3: Kampeni and Komunal Kitchen or Kuku Mama}

This building is located at the end of segment 5 and listed as building conservation Type B, which should have a maintained façade. This building also applied the Indo-European architecture style, which adapts to the tropical climate: a 45-degree roof slope, big windows, high ceiling and canopy. It was built in year 1920 as a residential house for a government officer, and later used as a residential house for an Indonesian Army officer after the independence.

In 2017, the house was used as "Kampeni and Komunal Kitchen" and changed its name into "Kuku Mama" in 2018.

Today all rooms inside the building have been demolished, but it is still keeping the authentic façade. The additional building was built in the surrounding area, where the right side is used for the kitchen and dining area; while shops are located at the left and back side.

The back garden still exists as an open space, which is also used for band performances; while the front yard is used as parking spaces.

The new concept building is Scandinavian, with an open plan for the dining area and kitchen. An additional column is needed to support the new structure concept. A curved column is considered not appropriate for the Dutch colonial architecture style.

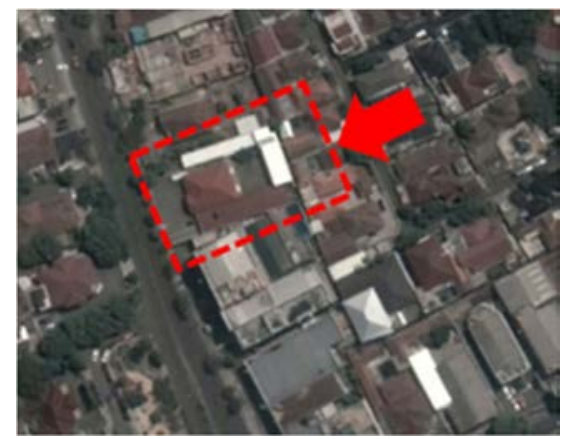

Figure 10: The location of Kuku Mama Restaurant is at segment 5 of Riau Street. (Source: Edited from Google Maps, 2018.)
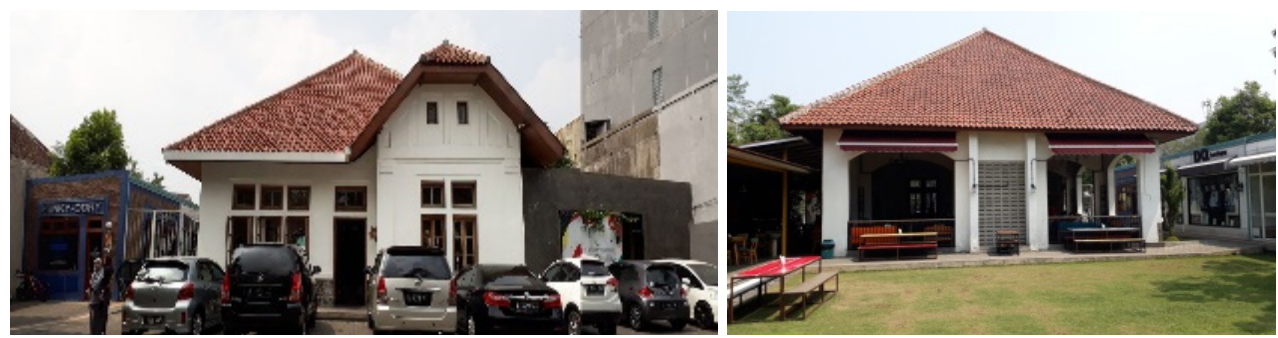

Figure 11: Current front and back yard elevation. (Source: Survey result, 2018.) 


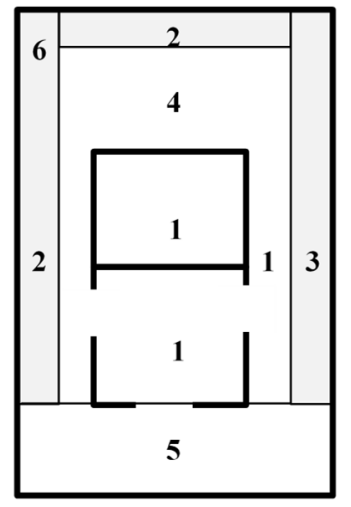

Legend:

1. Dining Area

2. Shop

3. Kitchen

4. Courtyard

5. Cashier \& Bar Counter

6. Service Area
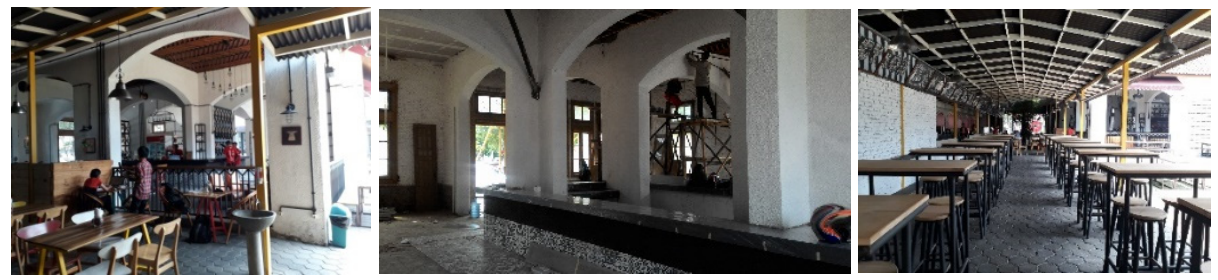

Figure 12: Current situation: the dining area is at the main building with a Scandinavian concept and there is an open dining room at an addition building. (Source: Survey result, 2018.)

\section{CONCLUSION}

From the three study cases above, it can be concluded that building functions encourage transformation. As the commercial function requires more space and more parking spaces, so addition space is needed. Space limitation leads to land optimization, by developing the remaining part of the lot. This situation has removed open spaces and changed it into a building or parking lot, so that there is no more open space or garden left for water absorption and oxygen production. This is believed to not be good for the city, because loss of water absorption can cause disasters such as flooding.

On the other hand, the adaptive re-use concept is considered to be successfully applied for building revitalization. The original shape and façade of a building could be maintained, while commercial needs could be fulfilled. The colonial building as a heritage building could still be maintained, and the area has changed over to be a unique commercial area, because of its beauty in the architecture style.

\section{ACKNOWLEDGEMENTS}

We acknowledge Menristek Dikti, who has provided funds for this research. To the LPPM (Research Institute and Community Service) Institut Teknologi Nasional go acknowledgements for supporting us and to Bandung Heritage, which provided the data used as the secondary field data.

\section{REFERENCES}

[1] Budihardjo, Arsitektur Pembangunan dan Konservasi, Djambatan: Semarang, 1997. 
[2] Avrami, E. et al., Value and heritage conservation, research report. The Getty Conservation Institute Heritage Studies, Stories in Making, Cambridge Scholar Publishing: Los Angeles, 2000.

[3] Wiliama, D.E., Sustainable Design, Ecology, Architecture and Planning, John Wiley and Sons, 2007.

[4] Widyastomo, D. et al., Setting transformation and the meaning of residence in Sentani's Tribe Tradition. Humanities and Social Sciences, pp. 37-45, 2015.

[5] Plevoets, B. \& Cleempoel, Adaptive reuse as strategy towards conservation of cultural heritage; a literature review. Structural Studies, Repairs and Maintenance of Heritage Architecture XII, Italy, ed. C.B. Terme, WIT Press: England, 2011.

[6] Voskuil, R.P.G.A., Bandoeng Beeld van een Stad, Asia Maior, 1999.

[7] Haryoto, K., Bandoeng Tempo Doeloe, Granesia: Bandung, 1984.

[8] Katam, S., Album Bandung Tempo Dulu, Khazanah: Bahari, 2010.

[9] Soewarno, N., Revitalization of historical buildings: adaptive re-use of Dutch colonial houses. Proceedings of 5th International Conference Modern Asian Architecture Network (mAAN), 2005. ISBN: 975-561-268-8.

[10] Karina Khoerunnisa, N., Muhammad Yogaswara, M., Andhika Dwi Faahrizal, A. \& Dwi Fitriani, P., Adaptive Reuse bangunan Cagar Budaya ada Kawasan Jl R.E Martadinata. Makalah Seminar Arsitektur, Institut Teknologi Nasional: Bandung, 2017. 